\title{
The 'weak pupil' as a social representation: (re)production in dialogue between compulsory school teachers in Sweden
}

\section{Therese Friberg ${ }^{1}$ (1)}

Received: 18 June 2020 / Accepted: 28 April 2021 / Published online: 26 May 2021

(c) The Author(s) 2021

\begin{abstract}
Attributing negative categories such as 'weak' to pupils is a common practice in Sweden and a known phenomenon worldwide. While there has been a substantial amount of research on different expressions of 'deviance' in the educational arena, the research on how teachers communicate about pupils as 'weak' is scarce. In this study, teachers' communication about pupils as 'weak' is examined in dialogues produced in focus group discussions by 29 teachers in six different Swedish compulsory schools. Through the lens of social representations theory and a dialogical perspective, this study suggests that 'weak pupil' as a social representation can be characterized by a range of different and sometimes contradicting themes and mainly two themata: normal/deviant and nature/nurture. The results show that 'weak pupil' is used as a multifaceted communicative resource to describe pupils who do not perform according to schools' expectations. In contrast to several previous studies, the use of 'weak pupil' is partially challenged by participants who, to some extent, place perceived problems within the educational institution instead of the individual pupil. The study has implications for the understanding of how perceptions of normality might be perceived and collectively (re)produced in communication about pupils as well as for future research using social representations theory within the educational field.
\end{abstract}

Keywords Weak pupil - Categorizations $\cdot$ Social representations $\cdot$ Themata $\cdot$ Focus group

Therese Friberg

tfr@du.se

1 Department of Teacher Education, Dalarna University, Falun, Sweden 


\section{Introduction}

One of the common values in education within the European Union is inclusion, which should provide "every child with a fair chance and equal opportunities to succeed" (European Commission, 2018, C195/1). A challenge for the profession is to meet all pupils without using stereotypical or overly negative categories. In Sweden, pupils who do not perform according to school expectations are often categorized in a way that reveals an institutional view of individual shortcomings rather than problems within the institution itself (Hjörne \& Säljö, 2017). One category that puts focus a on individual shortcomings is 'weak pupil'. Categorizations like 'weak' stigmatize pupils and may enhance their sense of exclusion (Larina \& Markina, 2019). Therefore, it is of high importance to develop a deeper understanding of this way of categorizing pupils. This study concerns teachers' communication about 'weak pupils'.

'Weak pupil' is a category present in Sweden as well as in other countries and languages around the world. This is not limited to the pedagogical arena but can also be found in the media context, as well as in international educational research (cf. Ch \& Saha, 2018; Damavandi \& Shekari Kashani, 2010; Janssen et al., 2006). Nor is this category of recent invention. Lundahl (2006) sees 'weak pupil' as a categorization connected to the modern era, and the term has featured regularly within a Swedish historical context. The term has been, and still is, (re)produced by institutions connected to knowledge assessment and has been motivated by their need for legitimization, communication and positioning toward other institutions. Official discourses related to negative categories are often (re)produced from the desire to help pupils who do not perform according to institutional expectations. However, within an educational context, there are unofficial discourses tied to categorizations that are connected to resources. One aspect of categorization can be to justify institutional practice and reject institutional responsibility by producing understandings of what constitutes 'normality' in relation to pupils (Lundahl, 2006; Tideman, 2000).

\subsection{Pupils' expected performance}

Categorizations of pupils who do not perform according to the school's expectations can affect the expectations on pupil's capacities (Hjörne \& Säljö, 2014). In the mid-twentieth century, Rosenthal and Jacobson (1968) carried out an experiment that showed a psychological impact of expectations on performance, commonly referred to as the Pygmalion effect. One important implication of that study was that teachers' expectations of pupil's abilities affect how pupils perform Contemporary research has confirmed a relation between teachers' expectations and pupils' performance (Friedrich et al., 2015; Rubie-Davis et al., 2018).

Several studies carried out within a Swedish context have suggested that perceived problems in pupils' performance are often constructed from a school perspective. Ideas produced within schools as institutions can often suggest that perceived problems are the result of the individual pupil; questions about the impact of the school's pedagogical approach on pupils' performance are rarely discussed 
(Göransson et al., 2011; Hjörne \& Säljö, 2017; Isaksson, 2009; Isaksson et al., 2006; Karlsson, 2007; Nilholm et al., 2013; Siekkinen, 2017). At a national policy level, a higher focus on institutional shortcomings has been addressed in relation to educational problems rather than focusing on the individual pupil. However, this is not visible at a municipality level, where problems are, as stated above, often ascribed to the individual pupil (Göransson et al., 2011).

In contrast to this, in a rather different context, Suleiman et al., (2018) show how, in the secondary school system in Nigeria, the school itself is one of three factors teachers use to explain poor pupil performance. Sweden's continued focus on the pupil as the source of the problem is surprising because it has long been considered as having one of the most inclusive school systems in the world (Cameron \& Lindqvist, 2014).

To some extent, research has shown that accountability can have an impact on the extent to which teachers draw on categories when assessing pupils' performances. Krolak-Schwerdt et al. (2013) found that teachers with a lower level of accountability tended to draw on and use social categories when assessing students more than those with a higher degree of accountability. Research on the impact of expectationconfirming information on teacher judgement formation shows contradictory results of having an impact on the whole cognitive process and the formation of judgement in experienced teachers (Krolak-Schwerdt et al., 2013) and student teachers (Glock \& Krolak-Schwerdt, 2013) as well as to part of the process (Glock \& Krolak-Schwerdt, 2014).

As research has shown, the practice of categorization seems to affect both pupils' performance and teachers' judgement of that performance. Investigating teacher communication about 'weak pupils' is important in order to prevent low expectations and negative categories from influencing pupil's performance in a negative fashion.

\subsection{Positioning pupils}

Relational thinking is an important cognitive function when (re)producing representations (Marková, 2003; Marková et al., 2007) such as 'weak pupil'. Positioning a pupil as 'weak' presumes ideas of what characterizes other related categories (Marková, 2003; Markova et al., 2007), such as 'normal' or 'strong' in comparison to 'weak'. Hedegaard Hansen et al., (2018) find that teachers tend to construct ideas of a fictive 'normal' pupil to which real pupils are compared. Similar results are shown by Tuval and Orr (2009) where pupils are compared to teachers' views of an 'ideal' pupil.

Sorting pupils into hierarchical categories of 'weak','normal' and/or 'strong' occurs in many different school contexts (Larina \& Markina, 2019; Tuval \& Orr, 2009; cf. Lundgren, 2006). In their study of the tension between inclusion and stratification within an Israeli school context, Tuval and Orr (2009) find that, in spite of a clear inclusive goal, sorting pupils into categories of 'weak' and 'normal' still occurred although it was not compatible with the school's inclusive intentions. Similar stratifying results were found by Lundgren (2006), where teachers categorized 
pupils as 'weak' and 'very good'. In between, the teachers position the pupils they call 'the middle children'. Research on understandings of pupils' capacity to perform according to a school's expectations, as they might be portrayed by teacher's categorizations (Tuval \& Orr, 2009), or parents social representations (Räty, 2014; Räty et al., 2012) shows that these are often understood as a natural part of reality and not as a construction of the school environment. In these cases, it can be difficult for pupils to move, or be moved, outside the categories they have been positioned in.

A pervasive issue within the research on categorizations within education seems to evolve around institutional understandings of a sphere of 'normality' and its borders. Institutions need to define what lies outside this sphere, based on conditions and eligibility, and by doing so contribute to understandings of what is 'normal' and what is not (Lundahl, 2006; Tideman, 2000). Investigating the perceptions and categorization practices of pupils as 'weak' is important in order to make visible and gain knowledge about perceptions regarding normality within the school as an institution.

\subsection{The Swedish context}

In order to understand the context in which the study is performed, information about the Swedish school system is briefly presented in this section.

In Sweden, the school system is divided into two parts. The first part is compulsory and applies to children aged 6 to 15. The second part is voluntary and applies to children aged 16-18. Compulsory education is comprised of an initial pre-school year ${ }^{1}$ (förskoleklass), a foundation level (lågstadiet, Years 1-3), an intermediate level (mellanstadiet, Years 4-6) and an advanced level (högstadiet, Years 7-9). Voluntary education in Sweden is the equivalent of 'secondary school' and is free of charge, as is university education.

Pupils are evaluated according to national standards in Years 3, 6 and 9. Pupils are graded from Year 6. From then until Year 9 they are tested and accumulate grades for individual subject areas twice per year. If there is reason to suspect that a pupil will not reach the knowledge requirements for one or more subjects, additional support should be provided within the regular teaching (The Swedish Education Act, 2010). According to the Swedish Education Act, all pupils are entitled to extra help and specialized support when necessary; No medical diagnosis is required. Equal opportunities and inclusive schooling are important values in the Swedish educational system as well as in the other Nordic countries where education is expected to be equivalent for all pupils (Klette, 2018).

1 The initial pre-school year is compulsory but not part of grundskolan (the compulsory school). 


\section{Aim and research question}

As has been shown, categorizing pupils as 'weak' is a common trope in several different areas, institutions, and languages and among different professions with an interest in educational issues. It has been produced and reproduced throughout the twentieth century and is still an active categorization within institutions connected to education. Teachers, both individually and collectively, are known to categorize pupils as 'weak'. Prior research confirms that their expectations of pupils have consequences for pupils' performance and that their understanding of the reasons for poor pupil performance is often connected to internal factors within the individual pupil. Despite this background, it is notable that research concerning the concept of 'weak pupils' is scarce, as well as research into the ways teachers use and reason about it. Learning how teachers collectively represent pupils as 'weak' will help to understand how perceptions of normality within the educational field are produced and the possible impediments these beliefs can be for teachers' judgement about pupils' performance. Thus, the aim of this study is to develop a deeper understanding of compulsory school teachers' social representations about 'weak pupils'. The research question guiding the study is: How can teachers' social representations of 'weak pupils' be characterized?

Few studies have linked their investigation of pupils who do not perform according to school's expectations with social representations theory (SRT) (e.g., Linton, 2015; Tuval, 2014). SRT, which is the theoretical approach used in this study, provides the opportunity to study 'weak pupil' by focusing on knowledge that is collectively produced and shared through communication and interaction.

\section{Theoretical approach: social representation theory}

In this study, compulsory school teachers' talk about pupils as 'weak' is examined through the lens of social representations theory (SRT). This means that the way of categorizing pupils in an educational context is based on an idea that alternately governs and is governed by representations. The theory provides tools for exploring this idea by looking at how "social knowledges are produced and transformed in processes of communication and social interaction" (Jovchelovitch, 2007 p. 45). SRT is situated within a social psychological framework and is supported by a constructivist — as well as a discursively oriented-tradition (Wagner, 1998). The theoretical perspective implies that perceptions of pupils, teachers and education as a practice of assessment are socially and culturally composed.

An important point of departure for SRT is that people collectively produce mutual understandings about their surroundings which then develops into common sense knowledge. This common sense knowledge arises through social interactions and aims to make the world more comprehensible (Moscovici, 2001; 1961/2008). Social representations are, thus, dynamic; they produce behavior and relationships (Moscovici, 1961/2008; Abric, 1994). Moscovici (1961/2008) says 
that they not only produce behaviors, but also help to reinforce the environment in which the behavior takes place and makes sense. Thus, I regard social representations of 'weak pupils' as both (re)producing ways of talking about and relating to pupils and as a means of maintaining structures that enable stratification in schools.

The concept of dialogue plays a central part in this study. Some variations on the concept of dialogue are used in this article and may need clarification. Dialogue refers in part to a concrete, everyday meaning where at least two people communicate, either 'face to face' or via technology such as a computer or mobile phone. Dialogism encompasses a more abstract meaning of dialogue and forms the foundation on which the ontological and epistemological starting points for the study are based. It makes it possible to apply the concept of dialogue to a wider definition of communication, including exchanges between ideas, institutions, historical time periods, and groups (Linell, 2009).

Viewing the world through the lens of dialogism suggests a web of interdependent relations between humans, societies and culture. Dialogical relationships do not occur only in interpersonal communication, but also "within and between groups, subgroups, communities, societies and cultures" (Marková, 2003 p. 90). As communication takes place in a dialogical relationship between the Self and the Other, it is thus bound to a social process (Marková, 2003; 2016). It is within this social process that representations of 'weak pupils' are shaped.

In order to analyze and track social representations of 'weak pupil' in teachers' dialogue I use the theoretical concepts of themata, themes and discursive polyphasia. $^{2}$

Themata (singular 'thema') are the underlying elements of thought, usually in the form of dyadic oppositions, which constitute the underlying structure from which our social representations are born (Marková, 2003, 2015, 2017). They form a foundation for common sense knowledge. In addition, themata are basic ideas that have been embedded in human thinking for a long time without necessarily being directly expressed in discourse (Marková et al., 2007; Moscovici, 2001). They are held by individuals as well as groups on an unconscious level and are therefore difficult, if not impossible, to observe directly (Marková, 2015). Not all dyadic oppositions are themata, but long-lasting dyadic oppositions have the potential to become themata provided they "are sources of dispute, interest, negotiation, tension or conflict among individuals, groups and societies.” (Marková, 2017 p. 74).

Themata are sources for communication about objects - they provide a foundation from which representations are (re)produced. In this study, they are viewed as potential sources on which we ground our perceptions and shape representations of objects within the educational context. As stated, themata are not always expressed or verbalized directly in communication. Instead, themata manifest themselves in themes (Liu, 2004). A theme is here understood as "a phrase or sentence that identifies what a unit of data is about and/or what it

\footnotetext{
2 Also commonly referred to as cognitive polyphasia. In this study, discursive polyphasia is used to highlight the social context in which the concept is used (Provencher, 2011).
} 
means (Saldaña, 2013, emphasis in original, p. 175). Liu (2004) calls themes "pragmatic manifestations" of themata. Pragmatic manifestations and themata are themselves dialogically interdependent (Liu, 2004) and should therefore be studied together.

Discursive polyphasia (Wagner, 2007) highlight the ability to occupy and express a variety of different and sometimes contradictory ideas about objects at the same time. This pluralistic thinking is found in both individuals and social groups (Jovchelovitch, 2007). The concept stresses the plasticity and coexistence of different forms of knowledge. Jovchelovitch points out that "Instead of leaving behind forms of knowing socially treated as backwards, primitive or childish, human communities continuously draw on the resources different knowledges offer" (Jovchelovitch, 2007 p. 70). The concept of discursive polyphasia is used here to analyze inconsistencies in the way social representations are produced by the interconnection between themes and themata. Furthermore, I am interested in how discursive polyphasia is (re)produced on a group rather than on an individual level.

\section{Methods and materials}

Drawing on the study's aim and theoretical concepts, focus group discussions were used to investigate how teachers talk about 'weak pupils'. Previous studies (see Olsson, 2019; Anderström, 2017; Granbom, 2011) have proven focus group discussions to be a fruitful method to investigate how knowledge is produced and shared in an educational context. The method is "particularly useful for allowing participants to generate their own questions, frames and concepts and to pursue their own priorities on their own terms, in their own vocabulary" (Kitzinger \& Barbour, 1999: p. 5). Stewart and Shamdashani (2015) also point out that one of the method's advantage is the potential to study how participants produce discussion using their own words.

\subsection{Participants and data collection}

Considering the aim of the study, participants had to be teachers active within the Swedish compulsory school system. No further delimitations were made because of the notion that social representations of the study object move independently of possible demographic factors such as: gender, subject area or teaching experience. The study consisted of six focus groups, as below (Table 1): 
Table 1 Number of participants and recorded time

\begin{tabular}{lll}
\hline & Participants & $\begin{array}{l}\text { Recorded } \\
\text { time (min- } \\
\text { utes) }\end{array}$ \\
\hline FG* 1 $^{*}$ FG 2 & 6 & 35 \\
FG 3 & 5 & 59 \\
FG 4 & 4 & 43 \\
FG 5 & 5 & 39 \\
FG 6 & 5 & 51 \\
& 4 & 53 \\
\hline
\end{tabular}

Recorded time does not include time for instructions

*Focus group

The data were collected over a period of 20 months (2017-2019) in six different schools. The only criterion in the selection of schools that were contacted was that they were situated within reasonable travelling distance from my home municipality. A strategic random sample (Patton, 2015) like this, combined with a convenience sample (Palinkas et al., 2015), is one of the most common ways to recruit focus group participants (Stewart and Shamdasani, 2015). At each of the six schools, the principals were given the opportunity to allow their teachers to take part in a focus group discussion, regardless of their decision to take part in the research project or not. This was to provide teachers with an opportunity to discuss educational issues. All of the principals where the focus group discussions were conducted were positively attuned to this offer.

All of the focus groups were for convenience conducted at the schools where the teachers were employed. Hence, each focus group consisted of teachers who were colleagues. Since communication among teachers about pupils is the focus of this study, it seemed fruitful to conduct the focus groups where the participants normally interacted, together with people with whom they were likely to interact. A common critique of focus group studies is the management of group dynamics and the possibility of "group talk" situations, where participants conform to the group even if they disagree with it (Hennink, 2014). This study does not focus on individual opinions, but collectively produced communication.

Upon arriving at the schools, all teachers attending the meeting received information on how the group discussions were to be conducted and participants in the study signed a consent letter. All participants have been given fictitious names in order to protect their privacy and ensure confidentiality. The study was conducted according to the national ethical guidelines for social science research (The Swedish Research Council, 2017) and its procedures and instruments were approved by The Board of Research Education at the authors institution.

The study used a relatively low level of structure, called an "open discussion focus group", since the purpose was to investigate how participants themselves produce conversations based on a given stimulus material (Marková et al., 2007). The stimulus material was used at the outset to spark discussion within the focus 
groups and as a means to collect data. The material was used to steer the discussions so that they revolved around pupils who do not perform according to schools' expectations.

My role as a moderator was not to participate in the discussions but to listen, take notes and ask questions at the end if necessary. The notes have served as prompts to facilitate transcription and the participants were informed that no attempts at analysis would be made during the conversations. This was to avoid participants feeling uncomfortable. How participants produce dialogue makes visible how knowledge is created, shared and taken for granted.

The conditions were arranged so that the focus group discussions could be conducted during a regular staff meeting. The discussions were, thus, somewhat shorter than average focus group discussions.

\subsection{Data collection procedure}

The focus group discussions were held in a room chosen by the participants. As the participants arrived, they were asked to sit around a table. Small notes were placed upside down on the table. On each note was a quoted headline from a published text (see Appendix). Each one was different but all of them related to pedagogy in some way. The quotes had been selected using the following criteria. They needed to have been:

- Published in a newspaper or magazine of significance in the educational field and/or should refer to a statement made by a person or organization with a clear educational background or interest,

- Possible to place within the framework of pupils with different needs, and

- Written in Swedish and published after 2000.

Participants were asked to take one note at a time and discuss its content. They were informed about the quotes' function as a stimulus material (e.g., Granbom 2011; Marková et al., 2007) for discussion and that they were not expected to have read the original text from where the quotes were obtained. Also on the table were two voice recorders. During the first focus group, it became clear that there were too many quotes to discuss. To avoid a possible feeling of having to hurry, for the subsequent five focus groups only 3-6 quotes were put on the table at the same time (same order as in Appendix).

Critical questions about what constitutes 'weak pupil' were articulated in several of the dialogues. In each case where this occurred, I asked the participants at the end of the discussion to further elaborate on the question of what can be meant when talking about 'weak pupil'. 


\subsection{Data analysis}

The analytic process has been divided into the following sections:

Firstly, a transcription of the recorded material was made in close connection with the focus group discussions. Pauses, laughs and sounds of consent or disagreement were marked. Transcription quotes in the results section have been checked against the recordings to enhance accuracy.

Secondly, analysis of the characteristic features of the representations were made by using the concepts of themes and themata (Marková, 2017; Marková et al., 2007; Saldaña, 2013). The transcriptions were read through to gain a first impression of underlying themes and themata. Next, all themes connected to participants' notions of what constitutes 'weak pupil' were marked in the transcriptions. The themes that were then analyzed had to be relevant to the collectively produced dialogue pertaining to notions of 'weak pupil'. This study adopted a generous understanding of what participants collectively labeled as a relevant theme by allowing a minimal (encouraging) response to an utterance to be sufficient to make up a theme (cf. Linell, 2001). Themes consisting of an utterance and a minimal response are rare in this material, but to leave them out in favor of a stricter understanding of a theme would not do the material justice. All themes analyzed originate from discussions initiated by the stimulus quote-"School researcher: more weak pupils". "Weak pupil' also occurred in discussions stimulated by other quotes, presented both before and after "School researcher: more weak pupils", but was used in a more abstract way that made thematic identification difficult. After themes were identified, they were grouped together in discursive ${ }^{3}$ clusters. This was done through an inductive process whereby themes were grouped according to similarities and, gradually, discursive clusters became visible. The analysis of themes was redone after six weeks, and compared to the first analysis, to enhance accuracy. Some minor changes were made in connection with this follow-up analysis.

To find possible themata in the data, the working process used the following criteria. Themata were to be:

- Basic ideas that have been embedded in human thinking for a long time (Marková et al. 2007; Moscovici, 2001),

- In the form of dyadic oppositions (Marková, 2003, 2015, 2017),

- Inclusive and comprehensive, covering as many themes (from the first part of analysis) as possible - all themes should be covered by a thema or themata, and

- Appropriate in relation to the themes they reflect and refer to (cf. Elton, 1977).

Examining the themes that emerged gave me an overview of possible themata. These were then tested in relation to the abovementioned criteria.

\footnotetext{
3 In this study, I apply Wagner and Hayes' (2005) notion of discourse to what I call discursive clusters, which: "shall be understood as the total of dialogues in particular situations or on a particular topic... It has a structure and content that goes beyond the sentence and beyond a concrete dialogue or conversation." (p. 219).
} 
Finally, in order to find voices that contradicted the representations, further analysis of their characteristic features was made by using the concept of discursive polyphasia. As part of the analysis process, the participants' dialogues were examined for contradictory expressions or utterances when elaborating on the categorization of pupils as 'weak'.

\section{Results}

Analysis of the empirical data has shown how six groups of Swedish compulsory school teachers shared and produced 'weak pupil' as a social representation. The presentation of results follows the order of themes, themata and discursive polyphasia laid out in the data analysis section, above.

\subsection{Themes}

The data analysis revealed a web of themes that the participants used to represent pupils as 'weak'. These themes were related to seven discursive clusters. Figure 1, below, shows the themes that emerged as well as the discursive clusters to which the themes were tied. To enhance both uniformity and clarity, themes have been formulated as endings to the sentence 'Weak pupil' as a social representation can be understood in relation to...

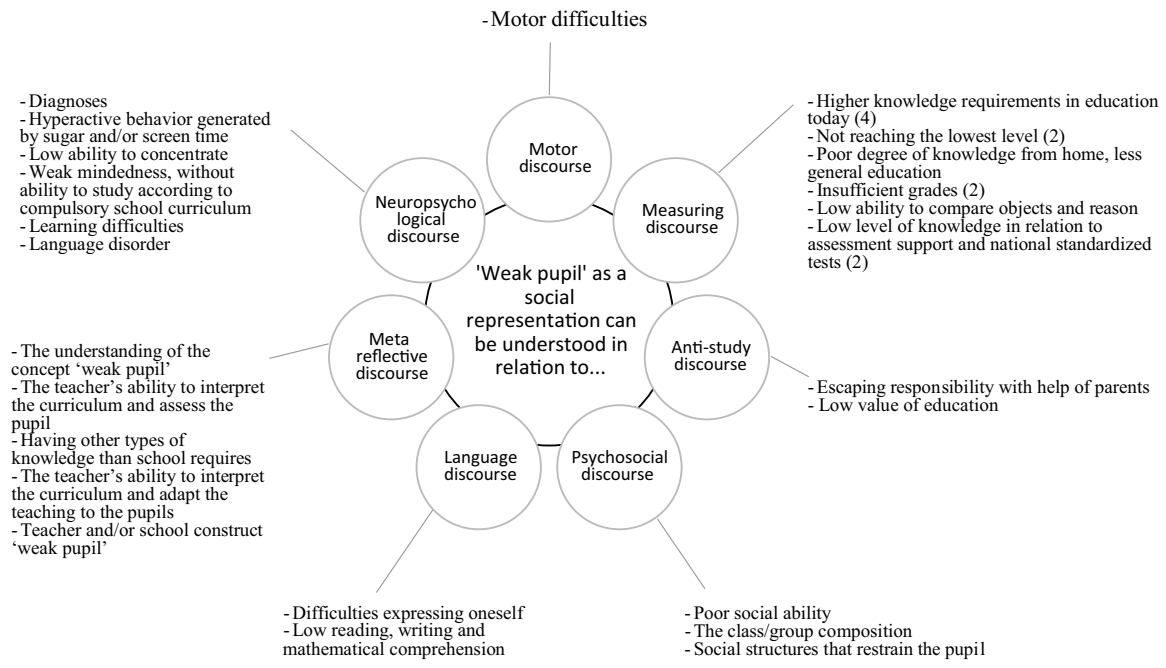

Fig. 1 Themes and discursive clusters. The number of utterances is placed in parentheses, if occurring more than once 
Themes and discourses are interconnected and, the borders between them are not as clear cut as it might appear in Fig. 1. The figure is not constructed to set boundaries between themes or discourses, or to define a definite way in which 'weak pupil' must be understood. Instead, it is used to show one way in which 'weak pupil' as a social representation can be (re)produced and how the identified themes, and the discursive clusters to which themes are tied, relate to each other. Excerpt 1, below, exemplifies how two different themes emerged and were identified:

Transcription key (concerns excerpt 1-9 below):

FG-focus group.

$\mathrm{x}$-unidentified voice.

$\mathrm{xy}$ - several unidentified voices.

*-assent.

...-pause.

I-interruption.

[number]—number of sentences not transcribed.

Excerpt 1:

FG 1

\begin{tabular}{|c|c|}
\hline Ahl & $\begin{array}{l}\text { Well it is true that we... so the pupils today are weaker yes maybe when it comes to vocabu- } \\
\text { lary and reading ability (x: yes } \mathrm{x}: \mathrm{mmh} \text { ), but they are significantly stronger in other... }\end{array}$ \\
\hline $\mathrm{X}$ & Social ability is also worse right? \\
\hline Ahl & Yes \\
\hline Asp & $\begin{array}{l}\text { That's the one I'm thinking about (Ahl: yes) it may well be the one that is dipping the most } \\
\text { (Ahl: yes) }\end{array}$ \\
\hline & [2] \\
\hline Asp & $\begin{array}{l}\text { Social codes, social interaction (Ahl: yes) relations, uh, how to interact with their classmates } \\
\text { and with other people (x: yes) }\end{array}$ \\
\hline Andersson & That will be the new school subject I think (xy: mmh) social skills \\
\hline
\end{tabular}

At the beginning of Excerpt 1, participants are having a brief discussion of vocabulary and reading comprehension in relation to 'weak pupil'. As is suggested by Ahl's first utterance, these topics had been discussed earlier, yet this utterance alone was sufficient to make it a theme in the analysis, namely low degree of vocabulary and reading comprehension. The participants then move on to discuss what was interpreted as the theme of poor social ability for the rest of the section.

Some examples of themes where participants discuss the role of the school and/or the educator in the creation of 'weak pupils' were found in this further elaboration, labeled Excerpt 2:

Excerpt 2:

FG6 


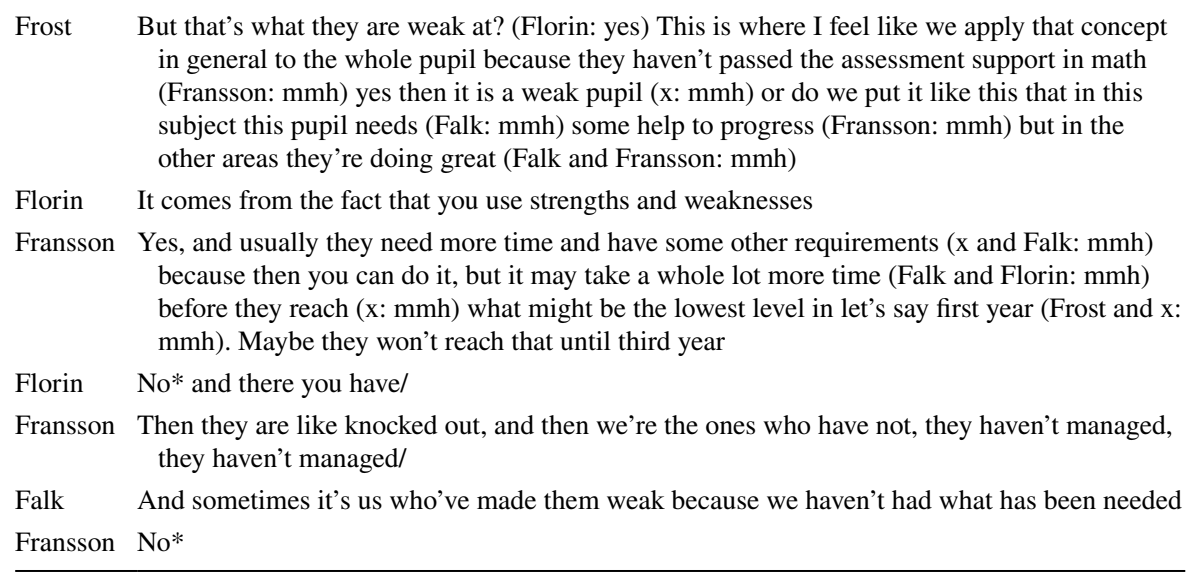

The dialogue here took a metareflective turn when Frost poses the question of what really constitutes 'weak pupil'. In the next section, Falk points out that sometimes pupils are constructed as 'weak' by their teachers.

\subsection{Themata}

Drawing on the concept of themata, two possible themata underlying and organizing the production of 'weak pupil' as a social representation were found. The most prominent seems to be a thema of normal/deviant. Of the themes (re)produced in the focus group discussions, and outlined in Fig. 1, notions of what constitutes normal and deviant organizes several of them. Themes which highlight understandings of deficiency, such as "insufficient grades", "not reaching the lowest levels", or "diagnoses" are defined in relation to understandings of what it means to have sufficient grades, to reach the lowest level and not have a particular diagnosis.

Nature/nurture was another thema which seemed to be activating themes constructing 'weak pupil' as a social representation. When looking at the themes related to metareflective discourse, it can be seen that participants questioned the concept of 'weak pupil' and directed their concerns about it away from pupils themselves and towards the school as an institution. Falk's utterance "And sometimes we're the ones who've made them weak because we haven't had what has been needed" (Excerpt 2) is an example of this. At the same time, several other themes show that participants linked 'weak pupil' with a measuring or biomedical discourse and seem to locate perceived problems within the pupil themselves.

It is important to stress that a theme could be organized by more than one thema - one thema did not exclude another. Both normal/deviant and nature/nurture could be organizers of a theme like "poor social ability" (Fig. 1). In either case, nor$\mathrm{mal} / \mathrm{deviant}$ and nature/nurture covered all of the themes (Fig. 1). 


\subsection{Discursive Polyphasia}

There were contradictory voices in the material, suggesting the presence of discursive polyphasia. This was exemplified when the participants were asked about the categorization of pupils as 'weak'. The participants criticized the lack of clarity around the concept, as illustrated in Excerpt 3, 4, 5 and 6:

Excerpt 3:

FG 2

Berg We had a lot with us from the beginning, if we try to integrate (xy: mmh) everyday life into school (xy: $\mathrm{mmh}$ ), which means that more weak pupils... I agree with the statement and then maybe we need to look more closely at what it is we mean if we say they find it harder, that they have learning difficulties $(\mathrm{x}: \mathrm{mmh})$ difficulty concentrating $(\mathrm{x}: \mathrm{mmh})$ or if it is when they come to school they have less competence than we had 10,15 or 20 years ago

\section{Excerpt 4:}

FG3

Cox It depends on how you measure things. Weak is a strange concept (x: mmh) (x: laugh). No, it depends on what we are measuring

\section{Excerpt 5:}

FG1

\begin{tabular}{ll}
\hline Andersson & I think about our use of this concept (x: mmh)/ \\
Amnell & But are they weak? \\
Andersson & weak pupils... Who do we mean? Do we always think about the ones with little ability? \\
Ahl & No, I don't think so \\
Andersson & $\begin{array}{l}\text { Neither do I (x: no*) (x: there are also the ones with knowledge/) because we talk at } \\
\text { almost every meeting (Ahl: yes) about weak pupils. So that is what we are talking } \\
\text { about }\end{array}$ \\
\hline
\end{tabular}

\section{Excerpt 6:}

FG6

Florin

Fransson

Florin
Yes, but when you read such things about weak pupils, well weak in what? Yes

What are they weak at? (Fransson: $\mathrm{mmh}$ )

At the same time, when 'weak pupils' appeared in a later quote, the discussions flowed around 'weak pupil' as a seemingly natural starting point for all groups. Cox, who had recently questioned 'weak' in relation to pupils (see Excerpt 4) continued shortly after this statement to say:

Excerpt 7:

FG3 
Cox Some want pupils to be grouped by level, so that the weak should be in one group and try to move up from that group and the strong ones... but the research (x:mmh) says that if they're mixed up then you strengthen the weak and the strong (xy:mmh x:exactly)

In FG 3, Cox first initiated a metareflective discussion on the use of 'weak pupil' by questioning this way of categorizing pupils (Excerpt 4). However, they (re)produced it shortly afterwards in a discussion about group leveling (Excerpt 7). In both of the examples from FG3 (Excerpts 4 and 7), these contradictory voices, like Cox's utterances, were (re)produced collectively by agreement (through expressions like "precisely" and "mmh").

In spite of a questioning of the categorization of pupils as'weak', there seemed to be a collective understanding of this way of communicating about pupils. Participants in FG6 stated this explicitly:

\title{
Excerpt 8:
}

FG6

\author{
Falk It feels like now while we're sitting here, it is clear that when we talk about weak pupils, we \\ know who it is we are talking about (Frost: $\mathrm{mmh}$; Florin: mmh yes) \\ Fransson Yes, yes, it is. That's right
}

Excerpt 8 shows the importance of collectively building the identity of the group (Abric, 1994). By announcing that "when we talk about weak pupils, we know who it is we're talking about" the participant (Falk) states the affinity between the individual teachers. They implicitly state that in their roles as teachers they have an unspoken, collective understanding of what they mean (that is, shared representations) when talking about pupils as 'weak'. That said, the same group, earlier on in the conversation, dialogically concluded that they found the communication of pupils as 'weak' problematic in the sense that it was unclear (see Excerpt 6). It seems appropriate to mention that there are remarkably few episodes in the dialogues where the participants disagreed. In only one of the focus group discussions was the construction of pupils as 'weak' questioned:

Excerpt 9:

FG3 
After questioning Cox's first statement, that weakness could relate to physical strength, participants then seemed to collectively agree that 'weak pupil' was more closely related to cognitive functions.

To sum up, the results from the empirical material show that a variety of themes were manifested in discussions about pupils as 'weak'. These themes were drawn into seven discursive clusters: measuring discourse, metareflective discourse, biomedical discourse, psychosocial discourse, language ability discourse, anti-school discourse and a motor discourse. Themes seemed to be invoked by two themata: normality/deviance and nature/nurture. Participants engaged in a degree of discursive polyphasia during the discussions by expressing the view that the use of "weak pupil' in their communication was a problematic concept. Yet, at some point after questioning the categorization, continued to use it as a natural basis for discussion.

\section{Discussion}

This section begins with a result discussion followed by comments on limitations of the study, suggestions for future research and conclusions.

\subsection{Result discussion}

The current study aimed to develop a deeper understanding of compulsory school teachers' social representations about 'weak pupils'. As the analysis of the focus group discussions has shown, the participants shared and explored social representations about 'weak pupils' by dialogically activating several different themes in relation to 'weak pupil'. These themes can be sorted into seven different discursive clusters. This implies that 'weak pupil' can be viewed as an umbrella concept under which a variety of issues can be accommodated which relate to pupils who do not perform according to school expectations. I argue that 'weak pupil' is a multifaceted concept because of its ability to manifest itself in a variety of different ways in different situations. One important contribution of this study is thus to highlight the diversity of meaning ascribed to the categorization of pupils as 'weak'. That said, participants still share a collective understanding of 'weak pupil' as a way of describing pupils. Differently put, using one of the participant's own words: "when we talk about weak pupils, we know who it is we're talking about". Yet, as the variety of themes connected to the representation of pupils as 'weak' suggest, there is 
a risk in communicative situations of ascribing attributes to a pupil which are not intended.

Categorizations are a necessary part of language and are used in "the process of bringing order to daily practices" (Hjörne \& Säljö, 2014, p. 253). However, as this study shows, talking about pupils as 'weak' means risking a consensus being taken for granted, when teachers might be activating different representations of 'weak pupil'. This becomes particularly problematic when teachers are engaged in assessment practices where this way of categorizing pupils might lead to miscommunication and meaning could be ascribed to a pupil which is not intended. It seems as if the plasticity of 'weak pupil' makes it both a useful and a potentially deceptive communication device.

Several studies on categorizations related to pupils who do not perform according to schools' expectations seem to focus on institutional understandings of normality and its periphery. In a similar fashion, this study suggests that 'weak pupil' as a social representation is organized from a thema of normal/deviant. Referring to a pupil as 'weak' suggests a deficiency perspective, which is mirrored in many of the themes participants (re)produced in the focus group discussions. In order to activate certain themes connected to a deficiency perspective, there must be an understanding of what is characteristic for the 'normal'. The talk of pupils as 'weak' in some discussions, then, seemed to activate the oppositional category of 'strong'. This is in line with previous findings where deficiency ascribed to pupils is understood in relation to the 'normal' or 'ideal' pupil (Hedegaard Hansen et al., 2018; Tuval \& Orr, 2009) and has important implications for the understanding of how normality might be perceived and collectively (re)produced in communication about pupils. The empirical findings support the theoretical notion of thinking in antinomies (Marková, 2003).

In contrast to previous findings (Tuval \& Orr, 2009), 'weak pupil' does not seem to be a self-evident way of talking, at least not entirely. It is challenged by the participants who, on several occasions during the focus group discussions, (re)produced themes related to a metareflective discourse. They questioned either their own or the institution's part in both categorizing pupils as 'weak' but also in creating situations for pupils where 'weak pupil' as a social representation was activated. This is contrary to several previous studies where categorizations connected to pupils who do not perform according to school-based expectations show that the pedagogical or institutional impact on pupils' performance are rarely elaborated upon (Göransson et al., 2011; Hjörne \& Säljö, 2017; Isaksson, 2009; Karlsson, 2007; Siekkinen, 2017). This result is more in line with Suleiman et al. (2018), who show how teachers in a Nigerian context perceive school-related factors as contributing to poor pupil performance. However, their study was based on the analysis of a questionnaire where statements had to be ranked on a four-point scale between "strongly disagree" and "strongly agree". These results are, therefore, based on participants' reactions to statements produced by other individuals, and not the outcome of participants' own and collectively generated reflections on poor pupil performance. Hence, it is difficult to compare this Nigerian study with other qualitative oriented studies, although it provides complementary findings on teachers' views on poor pupil performance. By (re)producing themes related to a metareflective discourse and a psychosocial 
discourse, it is suggested that teachers sometimes view deviance as an outcome of the school environment in which the pupil is located and not something residing within the pupil themselves. This suggests that a thema of nature/nurture partly activates the themes that constitute and organizes 'weak pupil' as a social representation. This result is similar to Räty's (2014) findings on Finnish parents' social representations on educability, where 'the idea of natural giftedness' and 'the idea of multifariousness of abilities and support for social equality' supported the relational categories of nature/nurture.

Though there are moments in several of the focus groups discussions where 'weak pupil' as a category were dialogically challenged by the participants, it was taken for granted in many occasions. The participants were engaging in discursive polyphasia, on the one hand, by questioning the categorization of pupils as 'weak' but, on the other hand, in later parts of the discussions, they took 'weak pupil' as a natural starting point for their dialogue. This shows that even though teachers challenge this way of categorizing pupils, the notion of 'weak pupil' seems to have a strong position in teachers' communication, to the point that it obtrudes itself into dialogue. That said, the coexistence of different and contradictory ideas can be used as a resource in communication (Jovchelovitch, 2007). Participants in this study seem to use 'weak pupil' as a communicative resource that describes a variety of pupils who do not live up to schools' expectations.

\subsection{Limitations}

There are certain limitations connected to this study. One concerns the unequal power relationship between the participants and the researcher. In this study, the stimulus material was used to form a relevant foundation for discussions and to provide a wide space for participants' own associations, ideas and opinions in their production of dialogues. By using a stimulus material, my role as a moderator was rather inobtrusive, although there is always a power relationship between the participants and the researcher (Kvale \& Brinkmann, 2014) which might have influenced the discussions here.

Another limitation concerns the use of the four criteria used in the analysis of themata. The theoretical concept of themata is used in this study to investigate what underlying ideas make 'weak pupil' as a social representation possible. Prior research where the concept of themata has been used provides little guidance in how to systematically find themata in empirical material. To apply this theoretical concept to the empirical data generated by this study, some criteria were implemented to make this process systematic and visible and thus, to enhance validity (e.g. Hennink, 2014). However, it should be stated that these criteria are, rightfully, vulnerable to critique. They might be considered too vague in their present form. Yet, by attempting to operationalize the concept of themata the intention is to add to the discussion of how a more systematic approach can be taken to the analysis of empirical material. This approach might also support the use of SRT in research looking to explore categorizations in educational settings. 
Despite the abovementioned limitations, the study provides important contributions to the understanding of teachers' social representations of 'weak pupils'. This study can be viewed as a contribution to a wider theoretical discussion about the future use of SRT within the educational field and the operationalization of the concept of themata using empirical material.

\subsection{Future research}

How communication about pupils as 'weak' affects the individual pupil is assumed theoretically and by previous research on categorization practices, but not empirically addressed in this study. Therefore, further empirical research on how pupils can be affected by this type of categorization is needed. This study does not focus on how perceptions of 'weakness' are fixed once pupils are socially represented as 'weak'. Research that looks to gain a deeper understanding of 'weak pupil' as a social representation, both amongst student teachers as well as in groups outside the educational field, is also necessary. Research on these groups would provide useful comparative information on whether representations of pupils as 'weak' can be viewed as a professional representation (Piaser \& Bataille, 2011) or if it operates "across minds" (Jovchelovitch et al., 1999, p. 96) outside the teaching profession. Research on social representations of 'weak pupils' within and outside the teaching profession would also expand understanding of the relationship between professional and/or scientific knowledge and common sense knowledge, which is a concern of SRT (Moscovici, 1961/2008; 2001). Finally, there is need for future research on how a more systematic approach can be taken to the analysis of themata in empirical material.

\section{Conclusion}

This study can be used to highlight compulsory school teachers' polyphasic construction of knowledge regarding pupils' performance and makes an empirical contribution to the studies surrounding the categorizations of pupils with different needs. The study has implications for the understanding of normality within the educational field. Additionally, it has implications for academic teaching programs concerned with teachers' professional language. Providing improved understanding of compulsory school teachers' social representations of 'weak pupils', the study implicates the importance of an accurate language to communicate about pupils, which should be of concern to student teaching programs.

\section{Appendix}

Different learning demand different teaching (Pedagogiska magasinet) Mars 2016. A school for all or just for a few? (LR). 
Level clustering back on the track (Lärarnas tidning) April 2010.

School researcher: More weak pupils (SvD) Dec 2013.

Quiet pupils and pupils acting out receive too little support (Lärarnas tidning) Mars 2005.

Earlier grades might lower weak pupils (Pedagogiska magasinet) Mars 2015.

Particularly gifted pupils need extra challenges (Pedagog Göteborg) Sep 2017.

Particularly gifted pupils are often overlooked (Special Nest) Nov 2017.

How do we meet impulsive pupils? (Lärkraft.se).

Research: Diagnoses risk putting school problems on pupils (Skolvärlden) Sep 2017.

(Specialpedagogik) Okt 2005.

How do we handle "disordely" children?

Funding Open access funding provided by Dalarna University.

Data availability The data that support the findings of this study are available from the author upon reasonable request.

\section{Declarations}

Conflict of interest The author declare that she has no conflict of interest.

Open Access This article is licensed under a Creative Commons Attribution 4.0 International License, which permits use, sharing, adaptation, distribution and reproduction in any medium or format, as long as you give appropriate credit to the original author(s) and the source, provide a link to the Creative Commons licence, and indicate if changes were made. The images or other third party material in this article are included in the article's Creative Commons licence, unless indicated otherwise in a credit line to the material. If material is not included in the article's Creative Commons licence and your intended use is not permitted by statutory regulation or exceeds the permitted use, you will need to obtain permission directly from the copyright holder. To view a copy of this licence, visit http://creativecommons.org/licen ses/by/4.0/.

\section{References}

Abric, J.-C. (1994). Pratiques sociales et Représentations [Social practices and eprésentations]. Presses Universitaires de France.

Anderström, H. (2017). Lärares samtal om etik: Sociala representationer av etikundervisning på mellanstadiet inom ramen för de samhällsorienterande ämnena [Teacher talk about ethics: Social representations of ethics education in social studies in school years 4-6]. Universitetstryckeriet.

Cameron, D. L., \& Lindqvist, G. (2014). School district administrators' perspectives on the professional activities and influence of special educators in Norway and Sweden. International Journal of Inclusive Education, 18(7), 669-685

Ch, D. R., \& Saha, S. K. (2018). RemedialTutor: A blended learning platform for weak students and study its efficiency in social science learning of middle school students in India. Education and Information Technologies, 24(3), 1925-1941

Damavandi, M. E., \& Shekari Kashani, Z. (2010). Effect of mastery learning method on performance, attitude of the weak students in chemistry. Procedia-Social and Behavioral Sciences, 5, 1574-11579

Elton, R. L. B. (1977). Methodological Themata in Educational Research. Research Intelligence, 3(2), 36-39 
European Commission. (2018). Council recommendation of 22 May 2018 on promoting common values, inclusive education, and the European dimension of teaching. file://dustaff/home/tfr/Windesk/SOU/ CELEX_32018H0607(01)_EN_TXT.pdf

Friedrich, A., Flunger, B., Nagengast, B., Jonkmann, K., \& Trautwein, U. (2015). Pygmalion effects in the classroom: Teacher expectancy effects on students' math achievement. Contemporary Educational Psychology, 41(3), 1-12

Glock, S., \& Krolak-Schwerdt, S. (2013). Does nationality matter? The impact of stereotypical expectations on student teachers' judgments. Social Psychology of Education, 16(1), 111-127.

Glock, S., \& Krolak-Schwerdt, S. (2014). Stereotype activation versus application: How teachers process and judge information about students from ethnic minorities and with low socioeconomic background. Social Psychology of Education, 17(4), 589-607.

Granbom, I. (2011). "Vi har nästan blivit för bra”: Lärares sociala representationer av förskolan som pedagogisk praktik ["We've almost become too good": Teachers' social representations of preschool as educational practice]. Jönköping University.

Göransson, K., Nilholm, C., \& Karlsson, K. (2011). Inclusive education in Sweden? A critical analysis. International Journal of Inclusive Education, 15(5), 541-555

Hedegaard Hansen, J., Jensen, C. R., Lassen, M. C., Molbæk, M., \& Schmidt, M. C. S. (2018). approaching inclusion as social practice: Processes of inclusion and exclusion. Journal of Educational and Social Research, 8(2), 9-19

Hennink, M. M. (2014). Focus group discussions: Understanding qualitative research. New York: Oxford University Press.

Hjörne, E., \& Säljö, R. (2014). Defining student diversity: categorizing and processes of marginalization in Swedish schools. Emotional and Behavioural Difficulties, 19(3), 251-265

Hjörne E., \& Säljö R. (2017). Categorizing Learners Beyond the Classroom. In: Wortham, S., Kim, D., \& May S. (Eds.), Discourse and Education. Encyclopedia of Language and Education (3 ${ }^{\text {rd }}$ ed.). Cham: Springer.

Isaksson, J. (2009). Spänningen mellan normalitet och avvikande: Om skolans insatser för elever i behov av särskilt stöd [The tension between normality and deviance: About the school's assistance for pupils in need of special support]. Umeå: Print och Media.

Isaksson, J., Lindqvist, R., \& Bergström, E. (2006). School problems or individual shortcomings? A study of individual educational plans in Sweden. European Journal of Special Needs Education, 22(1), 75-91

Janssen, T., Braaksma, M., \& Riljaarsdam, G. (2006). Literary reading activities of good and weak students: A think aloud study. European Journal of Psychology of Education, 21(1), 35-52

Jovchelovitch, S. (2007) Knowledge in Context. Representations, Community and Culture. New York: Routledge.

Jovchelovitch, S., Wagner, W., Duveen, G., Farr, R., Lorenzi-Cioldi, F., Marková, I., \& Rose, D. (1999). Theory and method of social representations. Asian Journal of Social Psychology, 2(1), 95-125

Karlsson, Y. (2007). Att inte vilja vara problem: social organisering och utvärdering av elever $i$ en särskild undervisningsgrupp (Not wanting to be a problem: social organization and evaluation of pupils in a special teaching group]. Linköping: LiU-Tryck.

Kitzinger, J., \& Barbour, R. S. (1999). Introduction: the challenge and promise of focus groups. In R. S. Barbour, \& J. Kitzinger (Eds.) Developing focus group research: politics, theory and practice. London: SAGE.

Klette, K. (2018). Individualism and collectivism in Nordic schools. A comparative approach. In Witoszek, M., \& Midttun, A. (Eds.) Sustainable Modernity. The Nordic Model and Beyond. New York: Routledge

Krolak-Schwerdt, S., Böhmer, M., \& Gräsel, C. (2013). The impact of accountability on teachers' assessments of student performance: A social cognitive analysis. Social Psychology of Education, 16(2), 215-239

Kvale, S., \& Brinkmann, S. (2014). Den kvalitativa forskningsintervjun [The qualitative research interview]. Lund: Studentlitteratur.

Larina, G., \& Markina, V. (2019). Hidden mechanisms of differentiation: teachers' beliefs about student diversity. Journal of Mathematics Teacher Education.

Linell, P. (2001). Approaching Dialogue. John Benjamins Pub. Co.

Linell, P. (2009). Rethinking, Language, Mind, and World Dialogically. Interactional and Contextual Theories of Human Sense-making. Charlotte: Information AgePublishing, INC. 
Linton, A-C. (2015). To include or not to include: Teachers' social representations of inclusion of students with Asperger syndrome. Linköping: LiU-Tryck.

Liu, L. (2004). Sensitising concept, themata and shareness: a dialogical perspective of social representations. Journal for the Theory of Social Behaviour, 34(3), 249-264

Lundahl, C. (2006). Viljan att veta vad andra vet. Kunskapsbedömning i tidigmodern, modern och senmodern skola [The desire to know what others know. Assessment of knowledge in early modern, modern and late modern education]. Stockholm: Elanders Gotab.

Lundgren, M. (2006). Från barn till elev i riskzon. En analys av skolan som kategoriseringsarena (From children to pupils at risk. An analysis of the school as a categorization arena). Göteborg: Intellecta Docusys.

Marková, I. (2003). Dialogicality and Social Representations. Cambridge: Cambridge University Press.

Marková, I. (2015). On Thematic Concepts and Methodological (Epistemological) Themata. Papers on Social Representations, 24(2), 4.1-4.31.

Marková, I. (2017). Themata in science and in common sense. Journal of Philosophy and Science, 19(1), 68-92

Marková, I., Linell, P., Grossen, M., \& Salazar-Orvig, A. (2007). Dialogue in Focus Groups. London: Equinox Publishing Ltd.

Moscovici, S. (2001). Social representations. Explorations in social psychology. New York: New York University Press.

Moscovici, S. (2008). Psychoanalysis. Its Image and Its Public. Cambridge: Polity Press. (Original work published 1961).

Nilholm, C., Almqvist, L., Göransson, K., \& Lindqvist, G. (2013). Is it possible to get away from disability-based classifications in education? An empirical investigation of the Swedish system. Scandinavian Journal of Disability Research, 15(4), 379-391

Olsson, Å. (2019). Finns det några kompetenta barn här? Pedagogers gemensamma föreställningar om barn i pedagogisk documentation [Are there any competent children here? Educators' common notions of children in educational documentation]. Tidskrift for Nordisk Barnehagsforskning, 18(2), $1-12$

Palinkas, L. A., Horwitz, S. M., Green, C. A., Wisdom, J. P., Duan, N., \& Hoagwood, K. (2015). Purposeful sampling for qualitative data collection and analysis in mixed method implementation research. Administration and Policy in Mental Health and Mental Health Services Research, 42(5), 533-544

Patton, M. Q. (2015) Qualitative research \& evaluation methods: integrating theory and practice: the definitive text of qualitative inquiry frameworks and options. Thousand Oakes, California: SAGE.

Piaser, A., \& Bataille, M. (2011). Of Contextualized Use of "Social" and "Professional". In Chaib, M., Danermark, B., \& Selander, S (Eds.) Education, Professionalization and Social Representations. On the Transformation of Social Knowledge. New York: Routledge

Provencher, C. (2011). Towards A Better Understanding of Cognitive Polyphasia. Journal for the Theory of Social Behaviour, 41(4), 377-395

Rosenthal, R., \& Jacobson, L. (1968). Pygmalion in the classroom. The Urban Review, 3(1), 16-20

Rubie-Davies, C. M., \& Li, Z. (2018). Teacher expectations in a university setting: The perspectives of teachers. Educational Research and Evaluation, 24(3-5), 201-220

Räty, H. (2014). Debating educability: Diverging social representations of abilities in Finnish educational discourse. Social Psychology of Education, 17, 457-469

Räty, H., Komulainen, K., \& Hirva, L. (2012). Social representations of educability in Finland: 20 years of continuity and change. Social Psychology of Education, 15, 395-409

Saldaña, J. (2013). The Coding Manual for Qualitative Researchers. (2nd ed.). London: SAGE.

Siekkinen, F. (2017). Flerspråkiga elever i en enspråkig elevnorm [Multilingual students in a monolingual pupil norm]. Educare, 1, 27-49

Stewart, W. D., \& Shamdashani, N. P. (2015). Focus groups: Theory and practice. London: SAGE.

Suleiman, Y., Suleiman, J. M., Musa, A. M., \& Abubakar, Y. A. (2018). Teachers' perceived factors of deviant behavior among secondary school students in Kwara state: Implication for educational managers. International Journal of Synergy and Research, 7, 59-79

Tideman, M. (2000). Normalisering och kategorisering. Om handikappideologi och välfärdspolitik i teori och praktik för personer med utvecklingsstörning (Normalization and categorization. About disability ideology and welfare policy in theory and practice for people with intellectual disabilities). Lund: Studentlitteratur.

The Swedish Research Council (2017). God forskningssed (Good Research Practice). Stockholm: The Swedish Research Council. 
The Swedish Education Act (2010). Skollag 2010:800 [Education Act 2010:800]. https://www.riksdagen. se/sv/dokument-lagar/dokument/svensk-forfattningssamling/skollag-2010800_sfs-2010-800

Tuval, S. (2014). Teachers Living with Contradictions: Social Representations of Inclusion, Exclusion and Stratification in Israeli Schools. Papers on Social Representations. 23(2), 10.1-10.25.

Tuval, S., \& Orr, E. (2009). Social representations of inclusion and stratification: ethnographic research within two Israeli elementary schools. Disability and Society., 24(4), 503-516

Wagner, W. (1998). Social representations and beyond: brute facts, symbolic coping and domesticated worlds. Culture and Psychology., 4(3), 297-329

Wagner, W. (2007). Vernacular science knowledge: Its role in everyday life communication. Public Understanding of Science., 16(1), 7-22

Wagner, W., \& Hayes, N. (2005). Everyday discourse and common sense. The theory of social representations. New York: Palgrave Macmillan.

Publisher's Note Springer Nature remains neutral with regard to jurisdictional claims in published maps and institutional affiliations.

Therese Friberg is a teacher and a Ph.D. student at the Department of Teacher Education at Dalarna University in Sweden. Her research interests focus on perceptions of normality within the school and other institutions connected to education, as well as the theory of social representations and its relevance for educational research. 